\title{
Dating the Late Proterozoic Stratigraphic Record
}

2

3 Galen P. Halverson ${ }^{1,2}$

4 Susannah M. Porter ${ }^{3}$

5 Timothy M. Gibson ${ }^{1}$ 93106, USA

\section{Abstract} tool.

1. Department of Earth and Planetary Sciences, McGill University, 3450 University St., Montréal QC, H3A 0E8 Canada

2. Earth Dynamics Research Group, ARC Centre of Excellence for Core to Crust Fluid Systems (CCFS) and The Institute for Geoscience Research (TIGeR), School of Earth and Planetary Sciences, Curtin University, GPO Box U1987, WA 6845, Australia

3. Department of Earth Science, University of California at Santa Barbara, Santa Barbara, CA

The Tonian and Cryogenian periods (1000-635.5 Ma) witnessed important biological and paleoclimatic events, including diversification of eukaryotes, the rise of alga as primary producers, the possible origin of Metazoa, and a pair of Snowball Earth glaciations. The Tonian and Cryogenian periods will also be the next in the geological time scale to be formally defined. Age-calibrating this interval is essential for properly ordering and interpreting these events and establishing and testing hypotheses for paleoenvironmental change. Here we briefly review the methods by which the Proterozoic time scale is dated and provide an up-to-date compilation of age constraints on key fossil first and last appearances, events, and horizons during the Tonian and Cryogenian periods. We also develop a new age model for a ca. 819-740 Ma composite section in Svalbard, which is unusually complete and contains a rich Tonian fossil archive. This model provides useful preliminary age estimates for the Tonian succession in Svalbard and distinct carbon isotope anomalies that can be globally correlated and used as an indirect dating 
36 Dating the geological record is essential for piecing together and interpreting the events and 37 processes that shaped Earth over its 4.54 billion-year history. One way in which geologists tell

38 time is through establishing the order in which events took place through application of the laws

39 of superposition and cross-cutting relationships. These basic yet powerful tools for telling

40 relative time, combined with biostratigraphy, enabled early geologists to formulate the

41 framework of a geological time scale long before methods for determining precise ages had been

42 developed ${ }^{1,2}$. However, accurate and precise ages are required to establish rates of processes and

43 calibrate unique events in Earth's history to absolute time ${ }^{3,4}$.

Radiometric techniques have been applied to dating geological materials since the pioneering work of Arthur Holmes over a century ago ${ }^{5}$. These techniques exploit a series of different isotopic systems in which a radioactive parent isotope decays into a stable daughter isotope. Many different radiometric dating methods are now regularly employed on a variety of materials ${ }^{6}$, and their utility and precision are steadily improving with better constraints on decay constants ${ }^{7}$, modification of sample preparation procedures to diminish extrinsic sources of error (e.g., ref. 8-10), and development of increasingly sophisticated and highly spatially resolved in situ analytical approaches ${ }^{11}$. These radiometric methods, combined with biostratigraphy, magnetostratigraphy, astrochronology, and other tools for correlating rocks globally, have calibrated a highly functional chronostratigraphic geological time scale (GTS) for most of the Phanerozoic Eon (541 million years ago [Ma] to present $)^{12}$.

Despite the great progress in calibrating and refining the GTS, telling time in the Proterozoic Eon (2500-541 Ma) remains a formidable challenge ${ }^{4,13}$. The difficulty lies partly in the limited utility of biostratigraphy and magnetostratigraphy in rocks of this age, compounded by a fragmentary and typically deformed sedimentary record. Fortunately, a rapidly growing database of geologically well-constrained radiometric ages (Figure 1; SI), combined with chemostratigraphy,

62 provides for an ever-improving geochronological framework for the Proterozoic Eon.

63 Consequently, certain events in Proterozoic Earth history, such as the onset of the Great

64 Oxidation Event (ca. $2420 \mathrm{Ma}^{14}$ ) and the end of the second (Marinoan) Snowball glaciation (ca. $65635.5 \mathrm{Ma}^{15-17}$ ) are reasonably well dated. Other important events, such as the first appearance of 66 animals and the massive ca. 570 Ma Shuram negative carbon isotope anomaly in the middle 
67 Ediacaran Period, remain poorly dated ${ }^{18-21}$. The aim of this contribution is to provide a brief

68 review of the methods by which the Proterozoic sedimentary record is temporally calibrated,

69 along with updated age constraints on key biological and geological events in the middle to late

70 Proterozoic (ca. 1050 to $635 \mathrm{Ma}$ ), which spans the proliferation of complex eukaryotes and a

71 second Proterozoic oxygenation event ${ }^{22}$. A well-resolved time scale is essential to reconcile the

72 processes responsible for the interconnected changes in the biosphere, oceans, atmosphere,

73 paleogeography, and climate during this key interval in Earth's history.

The mineral zircon dated by the uranium-lead $(\mathrm{U}-\mathrm{Pb})$ method is the gold standard of radiometric dating techniques. This zirconium silicate mineral $\left(\mathrm{ZrSiO}_{4}\right)$ crystallizes at high temperatures in felsic magmas and is an ideal geochronometer for multiple reasons. First, it incorporates uranium in trace amounts (100s to $1000 \mathrm{~s}$ of ppm), but does not incorporate lead, the ultimate daughter product of uranium decay, thus minimizing the need to correct for initial lead in the mineral in age calculations. Second, zircon is a highly durable mineral that can withstand the abuses of volcanic eruptions and multiple weathering and erosion cycles while retaining an isotopic imprint of its origin. Finally, because two separate isotopes of uranium $\left({ }^{235} \mathrm{U}\right.$ and $\left.{ }^{238} \mathrm{U}\right)$ decay to

83 two different isotopes of lead $\left({ }^{207} \mathrm{~Pb}\right.$ and ${ }^{206} \mathrm{~Pb}$, respectively), ages can be calculated from three 84 distinct isotopic ratios $\left({ }^{207} \mathrm{~Pb} /{ }^{206} \mathrm{~Pb},{ }^{207} \mathrm{~Pb} /{ }^{235} \mathrm{U},{ }^{206} \mathrm{~Pb} /{ }^{238} \mathrm{U}\right)$, providing a powerful internal check 85 on the reliability of the ages. Pre-screening (e.g., via imaging by secondary electron microscopy 86 and cathodoluminescence) to select the highest quality zircons, chemical pre-treatment to remove 87 mineral domains that are damaged and prone to lead $\operatorname{loss}^{8}$, and standardization of isotopic tracers and inter-laboratory calibrations, have led to great improvements in the precision and accuracy of $\mathrm{U}-\mathrm{Pb}$ ages $^{23}$.

91 The U-Pb isotopic data used to calculate ages are typically acquired via one of three analytical

92 approaches: isotope dilution thermal ionization mass spectrometry (ID-TIMS), secondary ion 93 mass spectrometry (SIMS, which includes the sensitive high-resolution ion microprobe, or 94 SHRIMP), or laser ablation inductively coupled plasma mass spectrometry (LA-ICP-MS). The 95 latter two methods involve in situ analyses, which are rapid and can target different domains 96 within individual zircons that may have grown at different times - and hence have different ages.

97 These advantages make in situ methods powerful and highly applicable to a wide range of 
geological problems. However, the precision of the ID-TIMS method, which entails dissolution

99 and analysis of a population of individual zircons (now commonly pre-screened by LA-ICP-

100 MS), yields analytical uncertainties that are 1-2 orders of magnitude better - now as low as

$101 \sim 0.01 \%$ or as low as $\pm 100,000$ years for zircons of late Proterozoic age ${ }^{23}$. The high precision

102 attainable by the ID-TIMS method makes it the benchmark for calibrating the GTS and

103 individual events in Earth's history ${ }^{3}$.

104

105 An important caveat in applying the $\mathrm{U}-\mathrm{Pb}$ zircon method to date the sedimentary record is that it 106 requires finding appropriate rock types: typically felsic to intermediate volcanic lava flows and 107 air fall tuffs (i.e., resulting from explosive eruptions) intercalated with sedimentary strata. These

108 volcanic rocks are not ubiquitous, for they are linked to specific tectonic settings, mainly 109 continental arcs and rift basins. Many passive margin and intracratonic basins, which dominate 110 the middle to late Proterozoic sedimentary record ${ }^{24}$, lack volcanic interbeds suitable for U-Pb 111 zircon dating. And even where ostensibly appropriate volcanogenic beds do occur, there is no 112 assurance that they will contain primary, dateable zircons.

114 Detrital zircon geochronology entails dating a large number of zircons (typically through in situ 115 analyses) that have been eroded from other sources and concentrated in sandstones and provides 116 an alternative approach to refining the possible age of poorly dated sedimentary sequences by 117 establishing the maximum possible age of a $\operatorname{rock}^{25}$. In some cases, these maximum ages, 118 combined with minimum ages established by other dating techniques, provide valuable age 119 constraints. Even when these data do not contribute meaningfully to dating stratigraphic 120 sequences, they can be a powerful tool for studying sediment provenance and global tectonic 121 cycles (e.g., 26, 27) and their possible links to global environmental change 2829 .

123 Another radiometric technique that has gained traction for dating the late Proterozoic record is 124 the rhenium-osmium (Re-Os) isotope system $\left({ }^{187} \mathrm{Re}-{ }^{187} \mathrm{Os}\right)$ applied to organic-rich rocks.

125 Rhenium and osmium are platinum group elements that occur in low abundance in the 126 continental crust but are relatively enriched in oxygenated seawater. Rhenium and osmium are 127 also organophilic and so hydrogenous phases of both elements occupy chelating sites on organic 128 complexes and are concentrated in organic-rich sediments during deposition and early 
129 diagenesis, typically in anoxic settings ${ }^{30-33}$. Selective leaching approaches that liberate only the

130 hydrogenous Re-Os fraction in sediments ${ }^{34,35}$, along with normalized isotopic spikes, and

131 analytical techniques that allow measurement of increasingly minute quantities of $\operatorname{Re}$ and

$132 \mathrm{Os}^{10,36,37}$, have greatly improved the reliability of this technique. Importantly, closed system

133 behavior of sedimentary rhenium and osmium has been shown to endure hydrocarbon

134 maturation, demonstrating that the Re-Os geochronometer is impervious to temperature and

135 pressure conditions up to greenschist facies ${ }^{38}$.

137 Although the precision in Re-Os ages $(\sim 1 \%)$ is much lower than that achievable with $\mathrm{U}-\mathrm{Pb}$, a

138 series of recent studies have shown that the technique yields consistent ages ${ }^{10,36,37}$. A striking

139 result of the application of Re-Os geochronology to the Proterozoic fossil record was a major

140 revision to the age of the fossil red alga Bangiomorpha pubescens in Arctic Canada, the oldest

141 taxonomically resolvable eukaryote ${ }^{39}$ and hence a key calibration point in molecular clock

142 analyses of early eukaryotic evolution ${ }^{40-42}$. Whereas earlier estimates based variably on

143 geological considerations and less robust radiometric dating methods implied an age close to

$1441200 \mathrm{Ma}$ for B. pubescens, a pair of Re-Os ages bracketing its occurrence in the Bylot

145 Supergroup, Baffin Island, constrain its age to $1045 \pm 15 \mathrm{Ma}$, with important implications for the

146 timing of primary plastid endosymbiosis ${ }^{43}$.

148 A flurry of recent $\mathrm{U}-\mathrm{Pb}$ and Re-Os ages from key stratigraphic sections globally that span the ca.

149 720-635 Ma Cryogenian period (which will soon be formally defined as the oldest period in the

150 GTS behind the ca. 635-540 Ma Ediacaran Period ${ }^{44}$ ) have demonstrated remarkable consistency

151 in the age of two Cryogenian (Sturtian and Marinoan) snowball glaciations globally (Fig. 1;

152 Supplementary Information). For example, the onset of the Sturtian glaciation is now tightly

153 constrained to have begun between 717.5 and 716.5 Ma based on U-Pb zircon ID-TIMS ages

154 acquired on volcanic rocks just below and just above the basal glacial contact in the Ogilvie

155 Mountains, Yukon ${ }^{50,51}$. Similarly, U-Pb zircon ages from the Marinoan glacial deposits ${ }^{15}$ and

156 overlying cap carbonates deposited in the immediate aftermath of Snowball glaciation ${ }^{16}$ date the

157 boundary between the Cryogenian and Ediacaran periods to 636.6 to 634.2 Ma. This boundary-

158 a so-called xenoconformity marking an abrupt global shift in environment ${ }^{52}$ - is placed at the

159 base of the cap carbonate and widely considered to be globally synchronous. Because it is an 
160 easily identifiable contact and occurs widely (it is known from every continent but Antarctica ${ }^{53}$ ), 161 this boundary is a unique calibration point in the geological record ${ }^{54}$.

163 Importantly, the radiometric ages bracketing the beginning and end of the Cryogenian glaciations

164 (see Table S1) provide a positive test for one of the key predictions of the Snowball Earth

165 hypothesis - long duration (millions of years) and synchronous onset and end to

166 glaciation ${ }^{49,55}$.These ages also serve to calibrate the Cryogenian non-glacial interlude (i.e., ca.

167 660-640 Ma) between the Sturtian and Marinoan cryochrons (Fig. 1), a critical interval in

168 Earth's history, which includes the first biomarker evidence for sponges ${ }^{56}$ and putative fossil

169 evidence for predatory Rhizaria ${ }^{57}$ (Table 1). In increase in the abundance of the $\mathrm{C}_{27}, \mathrm{C}_{28}$, and $\mathrm{C}_{30}$

170 steranes and sterane/hopane ratios during this interlude also indicate the rise to dominance of

171 eukaryotic algae as primary producers ${ }^{68}$.

172

173 Due to the vagaries of the geological record, certain sedimentary successions and time intervals

174 are especially well dated, such as the latest Tonian to early Cryogenian of northwestern Canada,

175 the southwestern USA, and South China (Table S1). Others are not. The Tonian period (1000 to

176 ca. $720 \mathrm{Ma}$ as currently defined ${ }^{44}$ ) overall is poorly calibrated radiometrically. Furthermore, the

177 Tonian sedimentary succession in Svalbard, perhaps the best preserved and most complete in the

178 world for this time period ${ }^{69,70}$ and a critical archive of important fossi1 ${ }^{39,60,62,71-73}$ and

179 geochemical ${ }^{69,74-78}$ data has not been directly dated. In the absence of direct radiometric ages,

180 easily identified GTS boundaries or biostratigraphic zonation (e.g., ref. 63,76), other approaches

181 are required to tell time in this and other successions for this time interval.

182

183 Chemostratigraphic correlation is one such tool with great utility in the Neoproterozoic Era ${ }^{79}$.

184 Chemostratigraphy relies on sedimentary materials, such as carbonate minerals or organic

185 carbon, that can be treated as dependable proxies for the isotopic composition of the seawater in

186 which they form. Using chemostratigraphy for correlation requires the additional assumptions

187 that the isotope system of interest is globally uniform in seawater (i.e., that it is has a long

188 residence time relative to the mixing time of the ocean) and can be reliably preserved in the rock

189 record. Commonly applied chemostratigraphic proxies for the Proterozoic Eon include carbon

$190\left(\delta^{13} \mathrm{C}\right)$, sulfur $\left(\delta^{34} \mathrm{~S}\right)$, and strontium $\left({ }^{87} \mathrm{Sr} /{ }^{86} \mathrm{Sr}\right)$ isotope ratios. Carbon isotope ratios are 
191 particularly useful in the Neoproterozoic because of the high amplitude and low frequency

192 fluctuations that characterize this time period (Fig. 1) and the abundance of well-preserved 193 carbonate successions. Although the Neoproterozoic Era was a time of generally high average $194 \delta^{13} \mathrm{C}$ values ( $+5 \%$ ), a series of deep negative $\delta^{13} \mathrm{C}$ anomalies punctuates this record (Fig. 1). 195 Some of these anomalies are temporally and causally closely associated with Neoproterozoic 196 glaciations $^{69,79}$, whereas others are not. For example, the so-called Bitter Springs Anomaly 197 (BSA; Figs. 1, 2), named after the eponymous formation in the Amadeus basin of central 198 Australia, is well defined in early-middle Neoproterozoic basins globally ${ }^{65,69,81,82}$, where it can 199 be confidently linked to the same global seawater perturbation based on broad age constraints, 200 other chemostratigraphic data (namely ${ }^{87} \mathrm{Sr} /{ }^{86} \mathrm{Sr}^{75}$ ), and its uniquely symmetric beginning and 201 end (Fig. 2). In the Fifteenmile Group of northwestern Canada, a U-Pb zircon date on a volcanic 202 tuff $^{50}$ and a Re-Os date on organic-rich rocks ${ }^{46}$ provide maximum age constraints on the onset of 203 the BSA of $811.51 \pm 0.25 \mathrm{Ma}$ and 815.29 $\pm 5.2 \mathrm{Ma}$, respectively. U-Pb ages zircon dates of $204815.29 \pm 0.32 \mathrm{Ma}$ and $778.72 \pm 0.24 \mathrm{Ma}$ on tuffs above and below the BSA in the Tambien Group 205 of Ethiopia ${ }^{65}$ are consistent with those from NW Canada and provide additional control on the 206 duration of the anomaly. These ages can be used to tell time indirectly in other, undated 207 successions, such as the Akademikerbreen Group in Svalbard, through chemostratigraphic 208 correlation (Fig. 2).

210 A second Tonian negative carbon isotope anomaly occurs in the upper Russøya Member of 211 Svalbard, above the Akademikerbreen Group and just below the Cryogenian (Sturtian)

212 Petrovbreen Member glacial deposits (Fig. 2). Whereas this negative carbon isotope anomaly had 213 previously been linked to the onset of Cryogenian glaciation ${ }^{80}$, new Re-Os age determinations 214 bracketing the likely correlative negative $\delta^{13} \mathrm{C}$ anomaly in northwestern Canada (the Coppercap 215 anomaly ${ }^{36,66}$ ) imply that it precedes the onset of Cryogenian glaciation by $>15$ m.y. (Fig. 1).

216 Through a combination of sequence stratigraphic and chemostratigraphic correlation, these ages

217 can be applied to the late Tonian strata in Svalbard ${ }^{70}$ (Fig. 2). In an analogous way, data from 218 other successions of overlapping age and completeness, can be mapped onto this composite 219 stratigraphic column and used to calibrate Tonian time. 
221 These and other correlated ages can further be used to develop a height-age model for the Tonian 222 stratigraphic succession in Svalbard. Where viable, subsidence models, which invoke the 223 tectonic mechanism for the generation of sedimentary basins, provide more geologically realistic 224 and accurate age-height relationships than simple linear interpolation between known (or 225 assumed) ages. When plotted against composite stratigraphic height, the Svalbard ages fall on an 226 exponentially decreasing curve (Fig. 3). This height-age relationship is predicted for thermally 227 subsiding basins whose subsidence is the result of cooling of lithosphere previously stretched by 228 extension $^{83}$. Sediment-loaded thermal subsidence curves can be calculated as a function of a 229 stretching factor $(\beta)$ based on the solution to the heat flow equation, using physical parameters 230 for the lithosphere, such as its thickness, density, and thermal conductivity. An assumption is 231 also required for where in the stratigraphic column thermal subsidence begins. Although the 232 tectonic context for the origin of the Neoproterozoic basin in Svalbard is not well understood ${ }^{70}$, 233 the contact between siliciclastic sediments of the Veteranen Group below and platformal 234 carbonates of the Akademikerbreen Group above is a reasonable approximation for the rift-drift 235 transition in Svalbard ${ }^{84}$ and is borne out by a systematic relationship between age and 236 stratigraphic height (Fig. 3). The best-fit subsidence curve for these data yields $\beta=1.263$ and $t_{0}$ $237=819.3 \mathrm{Ma}$ for the onset of rifting (i.e., the Veteranen-Akademikerbreen contact).

239 This subsidence age model estimates the timing of key stratigraphic horizons within the Svalbard 240 stratigraphic succession such as the onset (810 Ma) and end (802 Ma) of the Bitter Springs 241 Anomaly and the boundary between the Akademikerbreen and Polarisbreen groups (752 Ma). It

242 also provides age estimates for the local first appearance datum (FAD) and last appearance 243 datum (LAD) and of the possible index fossils Trachyshystrichosphaera aimika (805-795 Ma)

244 and Cerebrosphaera globosa (802-782 Ma), respectively (Table 1). The oldest putative 245 chlorophytes Proterocladus and Palaeastrum dyptocranum ${ }^{60}$, the possible stramenopile 246 Jacutianema solubila ${ }^{72}$, and the oldest amoebozoans ${ }^{59,62,54,86}$ all also occur in the Tonian strata of 247 Svalbard and can be assigned model ages (Table 1; Fig. 2). Dates for other important Tonian248 Cryogenian body fossil and molecular fossil first occurrences — such as apatite scale 249 microfossils ${ }^{46}$, possible Rhizaria ${ }^{57}$ and ciliates ${ }^{64}$, and the 24-isopropylcholestane sponge 250 biomarker ${ }^{56}$ - are also estimated based on available radiometric ages on the successions in which 251 the fossils were found or easily correlated equivalents (Table 1). 
253 These age assignments should not be treated as validation of the taxonomic interpretation of

254 these fossils. Rather, they should be combined with complementary approaches to querying and

255 quantifying the biostratigraphic record. Constrained optimization (CONOP) was recently

256 applied to estimating Tonian-Cryogenian species richness ${ }^{73}$, highlighting that the record is now

257 sufficiently resolved to apply biochronological and other statistical approaches. Indeed,

258 radiometric dating techniques alone are insufficient for precise calibration of the GTS ${ }^{87}$. Whereas

259 linear interpolation and spline-fitting techniques have traditionally been used for estimating ages

260 of GTS boundaries in the Phanerozoic record ${ }^{12}$, this approach is being superseded by Bayesian

261 statistical modelling, which is well suited to incorporating the many uncertainties intrinsic to

262 dating the stratigraphic record ${ }^{87,88}$. The Proterozoic record presents unique challenges to applying

263 these approaches, but an important first step is to construct composite stratigraphic sections onto

264 which available chronostratigraphic data can be mapped ${ }^{89}$, such as the Tonian-Cryogenian

265 section of Svalbard (Fig. 2). In this way, the Proterozoic GTS will gradually be filled in and

266 provide the chronological framework within which we may interpret the extraordinary events

267 that ushered in habitable Phanerozoic world.

Figure 1. (A) The Geological Time Scale (GTS) spanning the Neoproterozoic Era (modified

271 from ref. 12), along with a compilation of the carbonate Neoproterozoic $\delta^{13} \mathrm{C}$ record (modified

272 from ref. 45), with negative carbon isotope anomalies particularly useful for chemostratigraphic

273 correlations noted $(\mathrm{BSA}=$ Bitter Springs Anomaly; $\mathrm{CA}=$ Coppercap anomaly; $\mathrm{TA}=$ Trezona

274 Anomaly; SA = Shuram Anomaly). Fossil cartoons indicate (from bottom to top), first

275 appearance of algae $^{39,43}$, apatite scale microfossils ${ }^{46}$, the large ornamented Ediacaran

276 microfossils ${ }^{47}$, and the Ediacaran biota $^{48}$. Note that only the Ediacaran Period is formally defined

277 chronostratigraphically, but the Cryogenian period will soon be formalized and the

278 chronometrically defined Tonian period will likely be revised and subdivided

279 chronostratigraphically ${ }^{44}$. GSSP refers to formally defined global stratotype section and point

280 period boundaries. (B) The Sturtian and Marinoan (M) cryochrons (Snowball Earth events)

281 during the Cryogenian period with positions (open boxes) of the radiometric dates that constraint

282 their durations and appear to confirm their synchronous onsets and terminations (see also ref. 

49). Black squares are zircon and baddeleyite ID-TIMS dates, grey squares are in situ (SHRIMP 284 and SIMS) dates, and purple squares are Re-Os dates. See Table 1 for age estimates for the onset and end of the cryochrons based on these dates and SI Table 1 for a compilation of all of the dates, including their errors and literature sources.

Figure 2. A composite stratigraphic column through the Akademikerbreen Group and lower Polarisbreen Group (Russøya Member) of the Hecla Hoek Series of northeastern Svalbard (modified from ref. 70). Grey circles represent all available carbonate carbon isotope data for the succession mapped onto the composite stratigraphic column (from refs. 69, 70,80 and previously unpublished data), and the solid line a LOESS smoothing fit to these data. Approximate stratigraphic position of radiometric ages (in $\mathrm{Ma}$ ) that can be confidently correlated into the Akademikerbreen-Russøya section are shown in arrows (see SI Table 1 for sources of data), along with subsidence model ages (in Ma) for important stratigraphic heights, including the base of the Akademikerbreen Group, the onset and end of the Bitter Springs $\delta^{13} \mathrm{C}$ anomaly, and the Akademikerbreen-Polarisbreen contact. Stratigraphic LAD and FAD are for key fossil occurrences in Svalbard. See Table 1 for references and additional ages. Note that the LAD of the VSM is only loosely constrained to be within the Russøya Mb.

Figure 3. One dimensional McKenzie-type ${ }^{83}$ sediment-loaded thermal subsidence models for the long-term evolution of the East Svalbard basin (e.g., ref. 69) using the stratigraphic record of the Akademikerbreen Group and Russøya Member and correlated ages (open squares with age and approximate stratigraphic uncertainties). The key assumptions in the model are that thermal subsidence began with the base of the Akademikerbreen Group, which corresponds to the onset of nearly continuous carbonate deposition ${ }^{84}$, there was no major erosional unconformity in the succession, and that carbonate cementation occurred shortly after sedimentation (additional details on the application of this type of model to carbonate platforms can be found in ref. 85). The unconstrained parameters are the stretching factor $(\beta)$ and the timing of onset of thermal subsidence (open diamond; $t_{0}$ ); these were optimized using a chi-squared test. The resulting best

312 Akademikerbreen Group and Russøya Member. Additional subsidence curves for $\beta=1.25$ and

3131.30 shown for comparison. 
315 Table 1. Summary of key events, horizons, and biostratigraphic ranges, and first and last

316 appearance data for the latest Mesoproterozoic to Cryogenian geological record that can be

317 reliably estimated based on available radiometric ages and/or the subsidence-age model (Fig. 3)

318 for the latter Tonian stratigraphic succession in Svalbard. See Table S2 for additional ages for

319 stratigraphic heights and formation and member boundaries in Svalbard.

\section{References}

1. Williams, H.S., 1893. The making of the Geological Time-Scale. J. Geol. 1, 180-197.

2. Morrell, J. (2001) Genesis and geochronology: the case of John Phillips (1800-1874). In C.L.E. and S. J. Knell (Eds.) The Age of the Earth: from 4004 BC to AD 2002. Geo. Soc. London, Sp. Pubs., 190, 85-90.

3. Schmitz, M.D. (2012) Radiogenic isotope geochronology. In Gradstein, F.M., Ogg, J.O., Schmitz, M.D., and Ogg, G. (Eds.) The Geological Time Scale 2012, Elsevier, 114-126.

4. Knoll, A. H., and Nowak, M. A. (2017). The timetable of evolution. Science advances 3, e1603076.

5. Holmes, A. (1911) Association of lead with uranium in rock minerals and its application to the measurement of geological time. P. R. Soc. London 85, 248-256.

6. Rink, W.J., and Thompson, J.W. (2015). Encyclopedia of Scientific Dating Methods. Encyclopedia of Earth Sciences Series, Springer Reference (Dordrecht).

7. Condon, D. J., Schoene, B., McLean, N.M., Bowring, S.A., and Parrish, R.R. (2015). Metrology and traceability of the U-Pb isotope dilution geochronology (EARTHTIME Tracer Calibration Part I). Geochim. Cosmochim. Acta 164, 464-480.

8. Mattinson, J.M. (2005) Zircon U-Pb chemical abrasion ("CA-TIMS") method: Combined annealing and multi-step partial dissolution analysis for improved precision and accuracy of zircon ages. Chem. Geol. 200, 47-66.

9. Schmitz, M.D. and Schoene, B. (2007) Derivation of isotope ratios, errors, and error correlations for $\mathrm{U}-\mathrm{Pb}$ geochronology using ${ }^{205} \mathrm{~Pb}-{ }^{235} \mathrm{U}-\left({ }^{233} \mathrm{U}\right)$-spiked isotope dilution thermal ionization mass spectrometric data. Geochem. Geophys. Geosys. 8, 10.1029/2006GC001492.

10. Rooney, A.D., Austermann, J., Smith, R.F., Li, Y., Selby, D., Dehler, C.M., Schmitz, M.D., Karlstrom, K. E., and Macdonald, F. A. (2018). Coupled Re-Os and U-Pb geochronology of the Tonian Chuar Group, Grand Canyon. Geol. Soc. Am. Bull. 10.1130/B31768.1.

11. Nemchin, A.A., Horstwood, M.S.A., and Whitehouse, M.J. (2013) High-spatial resolution geochronology. Elements 9, 31-39.

12. Gradstein, F.M., Ogg, J.G., Schmitz, M.D., and Ogg, G.M. (2012) The Geological Time Scale 2012. Elsevier (Amsterdam).

13. Knoll, A. H. (2000) Learning to tell Neoproterozoic time. Precambrian Res. 100, 3-20.

14. Gumsley, A.P., Chamberlain, K.R., Bleeker, W., Söderland, U., de Kock, M.O., Larsson, E.R., and Bekker, A. (2017) Timing and tempo of the Great Oxidation Event. P. Natl. Acad. Sci. USA 114, 1811-1816. 
15. Hoffmann, K.H., Condon, D.J., Bowring, S.A., and Crowley, J.L. (2004) A U-Pb zircon date from the Neoproterozoic Ghaub Formation, Namibia: Constraints on Marinoan glaciation. Geology 32, 817-820.

16. Condon, D., Zhu, M., Bowring, S., Jin, Y., Wang, W., and Yang, A. (2005). From the Marinoan glaciation to the oldest bilaterians: U-Pb ages from the Doushantuo Formation, China. Science 308, 95-98.

17. Calver, C.R., Crowley, J.L., Wingate, M.T.D., Evans, D.A.D., Raub, T.D., and Schmitz, M.D. (2013) Globally synchronous Marinoan deglaciation indicated by U-Pb geochronology of the Cottons Breccia, Tasmania, Australia. Geology, 41, 1127-1130.

18. Pell, S. D., McKirdy, D. M., Jansyn, J., and Jenkins, R. J. F. (1993) Ediacaran carbon isotope stratigraphy of South Australia - an initial study. Trans. Royal Soc. S. Austr. 117, 153-161.

19. Burns, S., Haudenschild, U., and Matter, A. (1994) The strontium isotopic composition of carbonates from the Late Precambrian ( 560-540 Ma) Huqf Group of Oman. Chem. Geol. 111, 269-282.

20. Grotzinger, J.P., Fike, D.A., and Fischer, W.W. (2011) Enigmatic origin of the largest-known carbon isotope excursion in Earth's history. Nat. Geosc. 4, 285-292.

21. Husson, J.M., Maloof, A.C., and Schoene, B. (2012) A syn-depositional age for Earth's deepest $\delta^{13} \mathrm{C}$ excursion required by isotope conglomerate tests. Terra Nova 24, 318-325.

22. Lyons, T.W., Reinhard, C.T., and Planavsky, N.J. (2014). The rise of oxygen in Earth's early ocean and atmosphere. Nature 506, 307-315.

23. Schmitz, M.D. and Kuiper, K.F. (2013) High-precision geochronology. Elements 9, 25-30.

24. Bradley, D. C. (2011) Secular trends in the geologic record and the supercontinent cycle. Earth-Science Reviews, 108, 16-33.

25. Dickinson, W. R., and Gehrels, G. E. (2009). Use of U-Pb ages of detrital zircons to infer maximum depositional ages of strata: a test against a Colorado Plateau Mesozoic database. Earth Planet. Sc. Lett. 288, 115-125.

26. Voice, P.J., Kowalewski, M., Eriksson, K.A. (2011) Quantifying the timing and rate of crustal evolution: Global compilation of radiometrically dated detrital zircon grains. J. Geol. 119, 109-126.

27. Cawood, P.A., Hawkesworth, C.J., and Dhuime, B. (2013) The continental record and the generation of continental crust. Geol. Soc. Am. Bull. 125, 14-32.

28. McKenzie, N.R., Horton, B.K., Loomis, S.E., Stockli, D.F., Planavsky, N.J., and Lee, C.-T. (2016) Continental arc volcanism as the principal driver of icehouse-greenhouse variability. P. Nat. Ac. Sci. (USA) 352, 444-447.

29. Lee, C.-T., Yeung, L.Y., McKenzie, N.R., Yukoyama, Y., Ozaki, K., 2016. Two-step rise of atmospheric oxygen linked to the growth of continents. Nat. Geosc. 9, 417-424.

30. Ravizza, G. and Turekian, K.K. (1988). Application of the ${ }^{187}$ Re- ${ }^{187}$ Os system to black shale geochronometry. Geochim. Cosmochim. Acta 53, 3257-3262.

31. Colodner, D., Sachs, J., Ravizza, G., Turekian, K., Edmond, J. and Boyle, E. (1993) The geochemical cycle of rhenium: a reconnaissance. Earth Plan. Sc. Lett. 117, 205-221.

32. Crusius, J., Calvert, S., Pedersen, T., and Sage, D. (1996) Rhenium and molybdenum enrichments in sediments as indicators of oxic, suboxic, and sulfidic conditions of deposition. Earth Planet. Sc. Lett. 145, 65-78.

33. Yamashita, Y., Takahashi, Y., Haba, H., Enomoto, S. and Shimizu H. (2007). Comparison of reductive accumulation of $\mathrm{Re}$ and $\mathrm{Os}$ in seawater-sediment systems. Geochim. Cosmochim. Acta 71, 3458-3475. 
34. Selby, D., and Creaser, R.A. (2003) Re-Os geochronology of organic rich sediments: an evaluation of organic matter analysis methods. Chem. Geo. 200, 225-240.

35. Kendall, B., Creaser, R. A., Calver, C. R., Raub, T. D., and Evans, D. A. D. (2009) Correlation of Sturtian diamictite successions in southern Australia and northwestern Tasmania by Re-Os black shale geochronology and the ambiguity of "Sturtian"-type diamictite-cap carbonate pairs as chronostratigraphic marker horizons. Precambrian Res. 172, 301-310.

36. Rooney, A.D., Macdonald, F.A., Strauss, J.V., Dudás, F.Ö., Hallmann, C., and Selby, D. (2014). Re-Os geochronology and coupled Os-Sr isotope constraints on the Sturtian snowball Earth. P. Nat. Ac. Sci. (USA) 111, 51-56.

37. Rooney, A.D., Strauss, J.V., Brandon, A.D., and Macdonald, F.A. (2015) A Cryogenian chronology: Two long-lasting synchronous Neoproterozoic glaciations. Geology 43, 459462.

38. Creaser, R.A., Sannigraha, P., Chacko, T., and Selby, D. (2002) Further evaluation of the ReOs geochronometer in organic-rich sedimentary rocks: A test of hydrocarbon maturation effects in the Exshaw Formation, Western Canada Sedimentary Basin. Geochim. Cosmochim. Acta 66, 3441-3452.

39. Butterfield, N.J. (2000) Bangiomorpha pubescens n. Gen., n. sp.: Implications for the evolution of sex, multicellularity, and the Mesoproterozoic/Neoproterozoic radiation of eukaryotes. Paleobiology 26 386-404, https://doi.org/10.1666/0094.

40. Berney, C., and Pawlowski, J. (2006) A molecular time-scale for eukaryote evolution recalibrated with the continuous microfossil record. Royal Society of London Philosophical Transactions, Ser. B, 273, 1867-1872.

41. Parfrey, L.W., Lahr, D.J.G., Knoll, A.H., and Katz, L.A. (2011) Estimating the timing of early eukaryotic diversification with multigene molecular clocks. P. Nat. Ac. Sci. (USA) 108, $13,624-13,629$.

42. Eme, L., Sharpe, S.C., Brown, M.W., and Roger, A.J. (2014) On the age of eukaryotes: Evaluating evidence from fossils to molecular clocks. Cold Spring Harbor Persp. Bio. 6, a016139, https://doi.org/10.1101/cshperspect.a016139.

43. Gibson, T.M., Shih, P.M., Cumming, V.M., Fischer, W.W., Crockford, P.W., Hodgskiss, M.S.W., Wörndle, S., Creaser, R.A., Rainbird, R.H., Skulski, T.M., and Halverson, G.P. (2018) Precise age of Bangiomorpha pubescens dates the origin of eukaryotic photosynthesis. Geology 46, 135-139.

44. Shields-Zhou, G., Porter, S. A., and Halverson, G. P. (2016) A new rock-based definition for the Cryogenian Period (circa 720 - $635 \mathrm{Ma}$ ). Episodes 39, 3-9.

45. Cox, G. M., Halverson, G. P., Stevenson, R. K., Vokaty, M., Poirier, A., Kunzmann, M., Li, Z.-X., Denyszyn, S. W., Strauss, J. V., and Macdonald, F. A. (2016) Continental flood basalt weathering as a trigger for Neoproterozoic Snowball Earth. Earth Plan. Sci. Lett. 446, 89-99.

46. Cohen, P.A., Strauss, J.V., Rooney, A.D., Sharma, M., and Tosca, N. (2017) Controlled hydroxyapatite biomineralization in an $~ 810$ million-year-old unicellular eukaryote. Science Advances 3, e1700095.

47. Cohen, P.A., Knoll, A.H., and Kodner, R.B. (2009) Large spinose microfossils in Ediacaran rocks as resting stages of early animals. P. Natl. Acad. Sci. USA 106, 6519-6524.

48. Narbonne, G.M. (2004) Modular construction of early Ediacaran complex life forms. Science 305, 1141-1144. 
49. Hoffman, P.F., Abbott, D.S., Ashkenay, Y., Benn, D. I., Brocks, J.J., Cohen, P.A., Cox, G.M., Creveling, J.R., Donnadieu, Y., Erwin, D.H., Fairchild, I.J., Ferreira, D., Goodman, J.C., Halverson, G.P., Jansen, M.F., Le Hir, G., Love, G.D., Macdonald, F.A., Maloof, A.C., Partin, C.A., Ramstein, G., Rose, B.E.J., Rose, C.V., Sadler, P.M., Tziperman, E., Voigt, A., and Warren, S.G. (2017) Snowball Earth climate dynamics and Cryogenian geology and geobiology. Science Advances 3, e1600983.

50. Macdonald, F.A., Schmitz, M.D., Crowley, J.L., Roots, C.F., Jones, D.S., Maloof, A.C., Strauss, J.V., Cohen, P.A., Johnston, D.T., and Schrag, D.P. (2010) Calibrating the Cryogenian. Science 327, 1241-1243.

51. Macdonald, F.A., Schmitz, M.D., Strauss, J.V., Halverson, G.P., Gibson, T.M., Eyster, A., Cox, G., Mamrol, P., and Crowley, J.L. (2017). Cryogenian of Yukon. Precambrian Res., in press, 10.1016/j.precamres.2017.08.015.

52. Carroll, A.R. (2017) Xenoconformities and the stratigraphic record of paleoenvironmental change. Geology 45, 639-642.

53. Hoffman, P. F. and Li, Z. X. (2009) A palaeogeographic context for Neoproterozoic glaciation. Palaeogeog. Palaeoclim. Palaeoec. 277, 158-172.

54. Halverson, G.P. (2017) Introducing the Xenoconformity. Geology 45, 671-672.

55. Hoffman, P.F., Kaufman, A.J., Halverson, G.P., and Schrag, D.P. (1998) A Neoproterozoic snowball Earth. Science 281, 1342-1346.

56. Love, G.D., Grosjean, E., Stalvies, C., Fike, D. A., Grotzinger, J.P., Bradley, A.S., Kelly, A.E., Bhatia, M., Meredith, W., Snape, C. E., Bowring, S.A., Condon, D.J., and Summons, R.E. (2009) Fossil steroids record the appearance of Demosponges during the Cryogenian period. Nature 457, 718-721.

57. Bosak, T., Lahr, D.J.G., Pruss, S.B., Macdonald, F.A., Gooday, A.J., Dalton, L., and Matys, E. D. (2012) Possible early foraminiferas in post-Sturtian (716-635 Ma) cap carbonates. Geology, 40, 67-70.

58. Knoll, A.H., Wörndle, S., and Kah, L.C. (2013) Covariance of microfossil assemblages and microbialite textures across an upper Mesoproterozoic carbonate platform. Palaios 28, 453470 .

59. Knoll, A.H., Swett, K., and Mark, J. (1991) Paleobiology of a Neoproterozoic tidal flat/lagoonal complex: The Draken Conglomerate Formation, Spitsbergen. J. Paleont. 65, 531-570.

60. Butterfield, N. J., Knoll, A. H., and Swett, K. (1994). Paleobiology of the Neoproterozoic Svanbergfjellet Formation, Spitsbergen. Fossils and Strata 34, 1-81.

61. Martí Mus, M. (2001) Palaeobiology and taphonomy of early problematic fossil (Ph.D. dissertation). Uppsala University.

62. Riedman, L.A., Porter, S.M., and Calver, C.R. (2017). Vase-shaped microfossil biostratigraphy with new data from Tasmania, Svalbard, Greenland, Sweden and the Yukon. Precambrian Research, page 10.1016/j.precamres.2017.09.019.

63. Cox, G.M., Isakson, V., Hoffman, P.F., Gernon, T.M., Schmitz, M.F., Shain, S., Collins, A.S., Preiss, W., Blades, M.L., Mitchell, R.N., and Nordsvan, A. (in review) U-Pb zircon (CA-ID-TIMS) age supports globally synchronous Sturtian deglaciation. Precambrian Res.

64. Bosak, T., Lahr, D.J.G., Pruss, S.B., Macdonald, F.A., Dalton, L., and Matys, E. (2011) Aggutinated tests in post-Sturtian cap carbonates of Namibia and Mongolia. Earth Planet. Sc. Lett., 308, 29-40. 
65. Swanson-Hysell, N. L., Maloof, A. C., Condon, D. J., Jenkin, G. R. T., Alene, M., Tremblay, M. M., Tesema, T., Rooney, A. D., and Haileab, B (2015) Stratigraphy and geochronology of the Tambien Group, Ethiopia: Evidence for globally synchronous carbon isotope change in the Neoproterozoic. Geology 43, 323-326.

66. Strauss, J.V., Rooney, A.D., Macdonald, F.A., Brandon, A.D., and Knoll, A.H. (2014) 740 Ma base-shaped microfossils from Yukon, Canada: Implications for Neoproterozoic chronology and biostratigraphy $740 \mathrm{Ma}$ vase-shaped microfossils from Yukon, Canada: Implications for Neoproterozoic chronology and biostratigraphy. Geology 42, 659-662.

67. Prave, A.R., Condon, D.J., Hoffmann, K.H., Tapster, S., and Fallick, A.E. (2016) Duration and nature of the end-Cryogenian (Marinoan) glaciation. Geology 44, 631-634.

68. Brocks, J.J., Jarrett, A.J.M., Sirantoine, E., Hallmann, C., Hoshino, Y., and Liyanage, T. (2017) The rise of algae in Cryogenian oceans and the emergence of animals. Nature 548, 578-581.

69. Halverson, G.P., Hoffman, P.F., Schrag, D.P., Maloof, A.C., and Rice, A.H. (2005) Towards a Neoproterozoic composite carbon isotope record. Geol. Soc. Am. Bull. 117, 1181-1207.

70. Halverson, G.P., Kunzmann, M., Strauss, J.V., Maloof, A.C. (2017) The Tonian-Cryogenian transition in Svalbard. Precambrian Res. DOI: 10.1016/j.precamres.2017.12.010.

71. Knoll, A.H. (1982) Microfossil-based biostratigraphy of the Precambrian Hecla Hoek sequence, Nordaustlandet, Svalbard. Geol. Mag. 119, 269-279.

72. Butterfield, N. J. (2004). A vaucheriacean alga from the middle Neoproterozoic of Spitsbergen: implications for the evolution of Proterozoic eukaryotes and the Cambrian explosion. Paleobiology 30, 231-251.

73. Riedman, L.A. and Sadler, P.M. (2017) Global species richness record and biostratigraphic potential of early to middle Neoproterozoic eukaryote fossils. Precambrian Research. (doi:doi.org/10.1016/j.precamres.2017.10.008).

74. Knoll, A.H., Hayes, J.M., Kaufman, A.J., Swett, K., and Lambert, I.B. (1986) Secular variation in carbon isotope ratios from Upper Proterozoic successions of Svalbard and east Greenland. Nature 321, 832-837.

75. Halverson, G.P., Dudás, F.Ö., Maloof, A.C., and Bowring, S.A. (2007) Evolution of the ${ }^{87} \mathrm{Sr} /{ }^{86} \mathrm{Sr}$ composition of Neoproterozoic seawater. Palaeogeog. Palaeoclim. Palaeoec. 256, $103-129$.

76. Kunzmann, M., Bui, T.H. Crockford, P.W, Halverson, G.P., Scott, C., Lyons, T.W., and Wing, B.A. (2017) Bacterial sulfur disproportionation constrains timing of Neoproterozoic oxygenation. Geology 45, 207-210.

77. Kunzmann, M., Gibson, T.M., Halverson, G.P., Hodgskiss, M.S.W., Bui, T.H., Carozza, D.A., Sperling, E.A., Poirier, A., Cox, G.M., and Wing, B.A. (2017) Iron isotope biogeochemistry of Neoproterozoic marine shales. Geochim. Cosmochim. Acta, 209, 85-105.

78. Kunzmann, M., Halverson, G.P., Scott, C., Minarik, W.G., and Wing, B.A. (2015) Geochemistry of Neoproterozoic black shales from Svalbard: Implications for oceanic redox conditions spanning Cryogenian glaciations. Chem. Geol. 417, 383--393.

79. Kaufman, A. J., Knoll, A. H., and Narbonne, G. M. (1997) Isotopes, ice ages, and terminal Proterozoic Earth history. P. Nat. Acad. Sci. USA 95, 6600-6605.

80. Hoffman, P.F., Halverson, G.P., Domack, E.W., Maloof, A.C., Swanson-Hysell, N.L., and Cox, G.M. (2012) Cryogenian glaciations on the southern tropical paleomargin of Laurentia (NE Svalbard and East Greenland), and a primary origin for the upper Russøya (Islay) carbon isotope excursion. Precambrian Res. 206-207, 137-158. 
81. Hill, A. C. and Walter (2000) Mid-Neoproterozoic ( 830-750 Ma) isotope stratigraphy of Australia and global correlation. Precambrian Res. 100, 181-211.

82. Thomson, D., Rainbird, R. H., Planavsky, N., and Lyons, T. W. (2015) Chemostratigraphy of the Shaler Supergroup, Victoria Island, NW Canada: A record of ocean composition prior to the Cryogenian glaciations. Precambrian Res. 263, 232-245.

83. McKenzie, D. (1978) Some remarks on the development of sedimentary basins. Earth Planet. Sci. Lett., 40, 25-32.

84. Maloof, A.C., Halverson, G.P., Kirschvink, J.L., Schrag, D.P., Weiss, B., and Hoffman, P.F. (2006). Combined paleomagnetic, isotopic and stratigraphic evidence for true polar wander from the Neoproterozoic Akademikerbreen Group, Svalbard. Geol. Soc. Am. Bull. 118, $1099-1124$.

85. Halverson, G.P, Hoffman, P.F., Kaufman, A.J., and Schrag, D.P. (2002) A major perturbation of the carbon cycle before the Ghaub glaciation (Neoproterozoic) in Namibia: prelude to snowball Earth? Geochem. Geophys. Geosys. 3, 10.1029/2001GC000244.

86. Porter, S.M. and Knoll, A.H. (2000) Testate amoebae in the Neoproterozoic Era: evidence from vase-shaped microfossils in the Chuar Group, Grand Canyon. Paleobiology 26, 360385.

87. De Vleeschouwer, D. and Parnell, A.C. (2014) Reducing time-scale uncertainty for the Devonian by integrating astrochonology and Bayesian statistics. Geology 42, 491-494.

88. Parnell, A.C., Buck, C.E., and Doan, T.K. (2011) A review of statistical chronology models for high-resolution Holocene palaeoenvironmental reconstruction. Quatern. Sci. Rev. 30, 2948-2960.

89. Saddler, P.M. (2006) Composite time lines: a means to leverage resolving power from radioisotopic dates and biostratigraphy. Paleont. Soc. Papers 12, 145-170. 


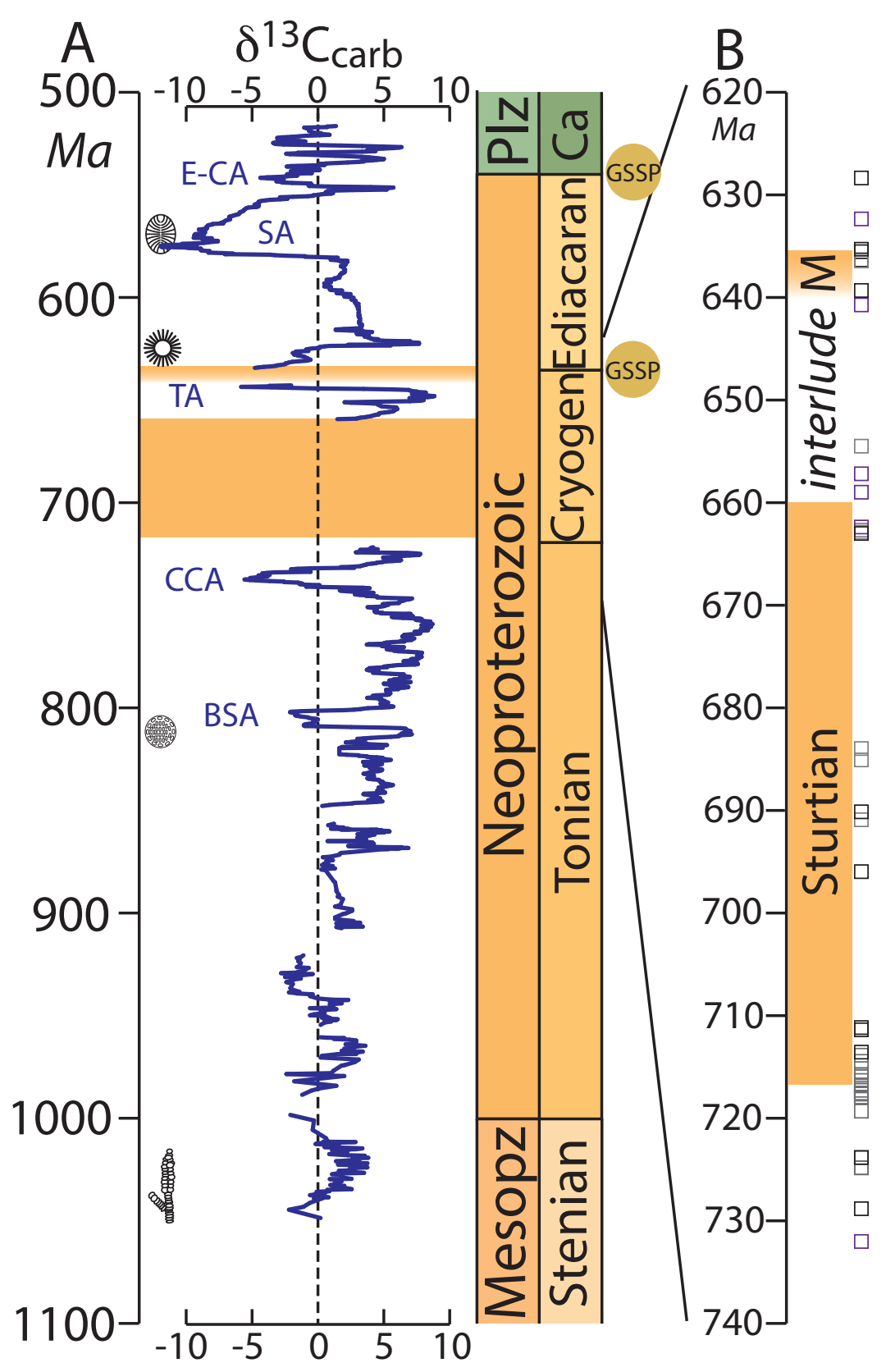




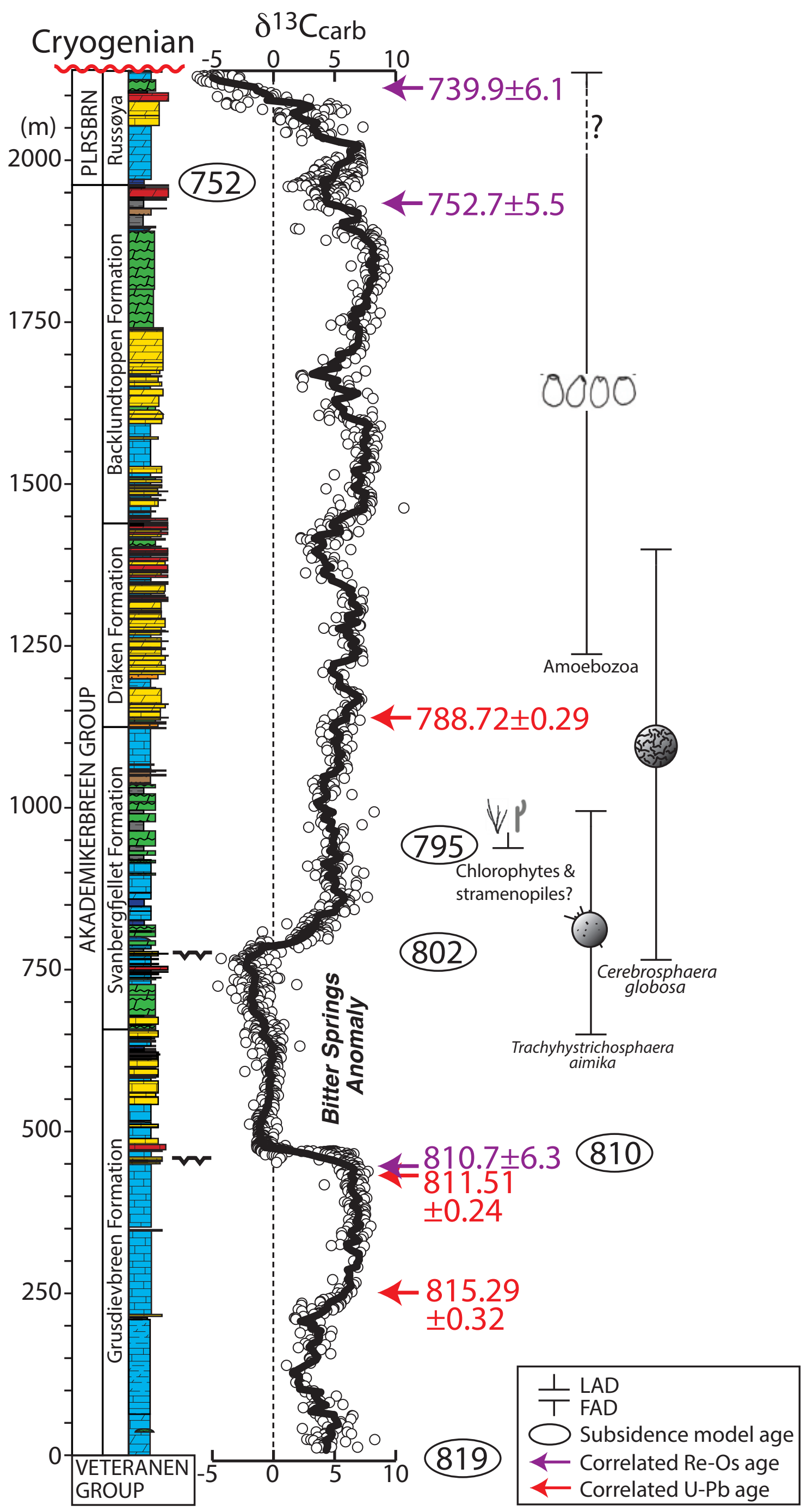


Event, FAD, LAD, or stratigraphic range

Rhodophyta (Bangiomorpha pubescens) (FAD)

Apatite scale microfossils (FAD)

Trachyhystrichosphaera aimika*

Cerebrosphaera globosa*

?Chlorophyta (Palaeastrum, Proterocladus)* (FAD)

Amoebozoa*

?Rhizaria (FAD)

?Tintinnids (FAD)

Sponge biomarkers

Base of Akademikerbreen Group

Onset of Bitter Springs Anomaly

End of Bitter Springs Anomaly

Coppercap $\delta^{13} \mathrm{C}$ anomaly minimum

Onset Sturtian glaciation

End Sturtian glaciation

Onset Marinoan glaciation

End Maronian glaciation/base Ediacaran Period

\section{Date}

$1045 \pm 15 \mathrm{Ma}$

$810.7 \pm 5.8 \mathrm{Ma}$

ca. 805-795 Ma

ca. 802-782 Ma

ca. $795 \mathrm{Ma}$

ca. $787 \mathrm{Ma}$

ca. $660 \mathrm{Ma}$

ca. $660 \mathrm{Ma}$

660-639 Ma

ca. $819 \mathrm{Ma}$

ca. $810 \mathrm{Ma}$

ca. $802 \mathrm{Ma}$

ca. $738 \mathrm{Ma}$

ca. $717 \mathrm{Ma}$

ca. $660 \mathrm{ma}$

ca. $640 \mathrm{Ma}$

ca. $635.5 \mathrm{Ma}$

\section{Method}

Re-Os

Re-Os

Subsidence model age

Subsidence model age

Subsidence model age

Subsidence model age

$\mathrm{U}-\mathrm{Pb}$ CA-TIMS + correlation

$\mathrm{U}-\mathrm{Pb}$ CA-TIMS + correlation

$\mathrm{U}-\mathrm{Pb}$ CA-TIMS + correlation

Subsidence model age

$\mathrm{U}-\mathrm{Pb}, \mathrm{Re}-\mathrm{Os}$, subsidence model age

$46,50,65$

Subsidence model age

Re-Os, subsidence model age

66

$\mathrm{U}-\mathrm{Pb}$

$\mathrm{U}-\mathrm{Pb}, \mathrm{Re}-\mathrm{Os}$

$\mathrm{U}-\mathrm{Pb}$

$\mathrm{U}-\mathrm{Pb}$
References

$39,43,58$

46

59,60

60

60

61,62

57,63

63,64

56,63

*In Svalbard 


\section{Table S1.}

Summary of age constraints on the begin and end of the Cryogenian glaciations and the Bitter Springs anomaly.

\section{Table S2.}

Ages for stratigraphic heights and formation/member boundaries generated using the thermal subsidence model for the Akademikerbreen-Russøya succession.

\section{References}

Baldwin, G. J., Turner, E. C., and Kamber, B. Z. (2016) Tectonic controls on distribution and stratigraphy of the Cryogenian Rapitan iron formation, northwestern Canada. Precambrian Res. 278, 303-322.

Bowring, S. A., Grotzinger, J. P., Condon, D. J., Ramezani, J., Newall, M. J., and Allen, P. A. (2007) Geochronological constraints on the chronostratigraphic framework of the Neoproterozoic Huqf Superroup, Sultanate of Oman. Am. J. Sci. 307, 1097-1145.

Calver, C.R., Crowley, J.L., Wingate, M.T.D., Evans, D.A.D., Raub, T.D., and Schmitz, M.D. (2013) Globally synchronous Marinoan deglaciation indicated by U-Pb geochronology of the Cottons Breccia, Tasmania, Australia. Geology, 41, 1127-1130.

Cohen, P.A., Strauss, J.V., Rooney, A.D., Sharma, M., and Tosca, N. (2017). Con- trolled hydroxyapatite biomineralization in an $~ 810$ million-year-old unicellular eukaryote. Science Advances 3, e1700095.

Condon, D., Zhu, M., Bowring, S., Jin, Y., Wang, W., and Yang, A. (2005). From the Marinoan glaciation to the oldest bilaterians: $\mathrm{U}-\mathrm{Pb}$ ages from the Doushantuo Formation, China. Science 308, 95-98.

Cox, G.M., Isakson, V., Hoffman, P.F., Gernon, T.M., Schmitz, M.F., Shain, S., Collins, A.S., Preiss, W., Blades, M.L., Mitchell, R.N., and Nordsvan, A. (in review) U-Pb zircon (CA-IDTIMS) age supports globally synchronous Sturtian deglaciation. Precambrian Res.

Cox, G.M., Strauss, J.V., Halverson, G.P., Schmitz, M.D., McClelland, W.C., Stevenson, R.S., and Macdonald, F.A. (2015) Kikiktat volcanics of Arctic Alaska-Melting of harzburgitic mantle associated with the Franklin large igneous province. Lithosphere 7, 275-295.

Eyster, A., Ferri, F., Schmitz, M. D., and Macdonald, F. A. (2018) One diamictite and two rifts: Stratigraphy and geochronology of the Gataga Mountain of northern British Columbia. Am. J. Sci. 318, 167-207.

Fanning, C. and Link, P. (2004) U-Pb SHRIMP ages of Neoproterozoic (Sturtian) glaciogenic Pocatello Formation, southeastern Idaho. Geology 32, 881-884. 
Hoffmann, K.H., Condon, D.J., Bowring, S.A., and Crowley, J.L. (2004) A U-Pb zircon date from the Neoproterozoic Ghaub Formation, Namibia: Constraints on Marinoan glaciation. Geology 32, 817-820.

Kendall, B., Creaser, R. A., and Selby, D. (2006) Re-Os geochronology of postglacial black shales in Australia: Consequences for timing of the Sturtian glaciation. Geology 34, 729-732.

Kendall, B., Creaser, R. A., Calver, C. R., Raub, T. D., and Evans, D. A. D. (2009) Correlation of Sturtian diamictite successions in southern Australia and northwestern Tasmania by Re-Os black shale geochronology and the ambiguity of "Sturtian"-type diamictite-cap carbonate pairs as chronostratigraphic marker horizons. Precambrian Res. 172, 301-310.

Lan, Z., Li, X., Zhu, M., Chean, Z.-Q., Zhang, Q., Li, Q., Lu, D., Liu, Y., and Tang, G. (2014) A rapid and synchronous initiation of the wide spread Cryogenian glaciations. Precambrian Res. 255, 401-411.

Lan, Z., Li, X.-H., Zhang, Q., and Li, Q.-L. (2015a) Global synchronous initiation of the 2nd episode of Sturtian glaciation: SIMS zircon $\mathrm{U}-\mathrm{Pb}$ and $\mathrm{O}$ isotope evidence from the Jiangkou Group, South China. Precambrian Res. 267, 28-38.

Lan, Z., Li, X.-H., Zhu, M., Zhang, Q., and Li, Q.-L. (2015b). Revisiting the Liantuo Formation in Yangtze Block, South China: SIMS U-Pb zircon age constraints and regional and global significance. Precambrian Res. 267, 123-141.

Lund, K., Aleinikoff, J.N., Evans, K.V., and Fanning, C. (2003) SHRIMP U-Pb geochronology of Neoproterozoic Windermere Supergroup, central Idaho: Implications for rifting of western Laurentia and synchroneity of Sturtian glacial deposits. Geol. Soc. Am. Bull. 115, 349-372.

Lund, K., Aleinikoff, J.N., Evans, K.V., duBray, E.A., Dewitt, E.H., and Unrah, D.M. (2010) SHRIMP U-Pb dating of recurrent Cryogenian and Late Cambrian-Early Ordovician alkalic magmatism in central Idaho: Implications for Rodinian rift tectonics. Geol. Soc. Am. Bull. 122, $430-453$.

Macdonald, F.A., Schmitz, M.D., Crowley, J.L., Roots, C.F., Jones, D.S., Maloof, A.C., Strauss, J.V., Cohen, P.A., Johnston, D.T., and Schrag, D.P. (2010) Calibrating the Cryogenian. Science 327, 1241-1243.

Macdonald, F.A., Schmitz, M.D., Strauss, J.V., Halverson, G.P., Gibson, T.M., Eyster, A., Cox, G., Mamrol, P., and Crowley, J.L. (2017) Cryogenian of Yukon. Precambrian Res., in press, 10.1016/j.precamres.2017.08.015.

Prave, A.R., Condon, D.J., Hoffmann, K.H., Tapster, S., and Fallick, A.E. (2016) Duration and nature of the end-Cryogenian (Marinoan) glaciation. Geology 44, 631-634. 
Rooney, A.D., Austermann, J., Smith, R.F., Li, Y., Selby, D., Dehler, C.M., Schmitz, M.D., Karlstrom, K. E., and Macdonald, F. A. (2018). Coupled Re-Os and U-Pb geochronology of the Tonian Chuar Group, Grand Canyon. Geol. Soc. Am. Bull. 10.1130/B31768.1.

Rooney, A.D., Macdonald, F.A., Strauss, J.V., Dudás, F.Ö., Hallmann, C., and Selby, D. (2014). Re-Os geochronology and coupled Os-Sr isotope constraints on the Sturtian snowball Earth. $P$. Nat. Ac. Sci. (USA) 111, 51-56.

Rooney, A.D., Strauss, J.V., Brandon, A.D., and Macdonald, F.A. (2015) A Cryogenian chronology: Two long-lasting synchronous Neoproterozoic glaciations. Geology 43, 459-462.

Schmitz, M.D. (2012) Radiogenic isotope geochronology. In Gradstein, F.M., Ogg, J.O., Schmitz, M.D., and Ogg, G. (Eds.) The Geological Time Scale 2012, Elsevier, 114-126.

Song, G., Wang, X., Shi, X., and Jiang, G. (2017) New U-Pb age constraints on the upper Banxi Group and synchrony of the Sturtian glaciation in South China. Geosc. Frontiers 8, 1161-1173.

Swanson-Hysell, N. L., Maloof, A. C., Condon, D. J., Jenkin, G. R. T., Alene, M., Tremblay, M. M., Tesema, T., Rooney, A. D., and Haileab, B (2015) Stratigraphy and geochronol- ogy of the Tambien Group, Ethiopia: Evidence for globally synchronous carbon isotope change in the Neoproterozoic. Geology 43, 323-326.

Tollo, R. P. and Aleinikoff, J. N. (1996) Petrology and U-PB geochronology of the Robertson River Igneous Suite, Blue Ridge province, Virginia - Evidence for multistage magmatism associated witn an early episode of Laurentian rifting. American Journal of Science, 296:10451090.

Xu, B., Xiao, S., Zou, H., Chen, Y., Li, Z.-X., Song, B., Liu, D., Zhou, C., and Yuan, X. (2009) SHRIMP zircon U-Pb age constraints on Neoproterozoic Quruqtagh diamictites in NW China. Precambrian Res. 168, 247-258.

Yu, W., Algeo, T. J., Du, Y., Zhou, Q., Wang, P., Xu, Y., Yuan, L., and Pan, W. (2017). Newly discovered Sturtian cap carbonate in the Nanhua Basin, South China. Precambrian Research, 293:112-130.

Zhang, Q.-R., Li, X.-H., Feng., L.-J., Huang, J., and Song, B. (2008a) A new age constraint on the onset of Neoproterozoic glaciations in the Yangze Platform, South China. The Journal of Geology 116, 423-429.

Zhang, S., Jiang, G., and Han, Y. (2008b) The age of the Nantuo Formation and Nantuo glaciation in South China. Terra Nova 20, 289-294.

Zhang, S., Jiang, G., Zhang, J., Song, B., Kennedy, M., and Christie-Blick, N (2005). U-Pb sensitive high-resolution ion microprobe ages from the Doushantuo Formation in south China: Constraints on late Neoproterozoic glaciations. Geology 33, 473-476. 
Zhou, C., Tucker, R., Xiao, S., Peng, Z., Yuan, X., and Chen, Z. (2004) New constraints on the ages of Neoproterozoic glaciations in south China. Geology 32, 437-440. 


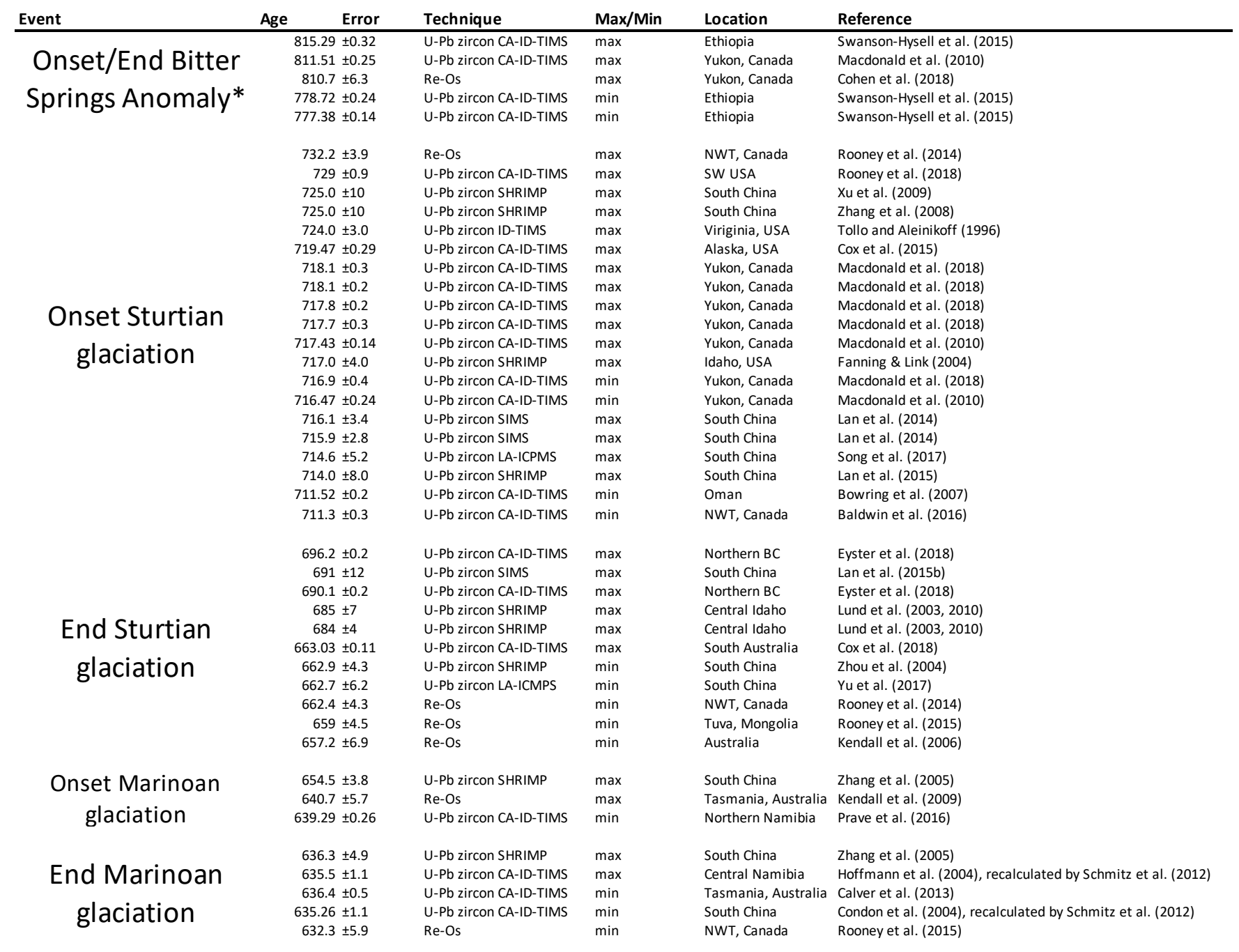

*Age constraints are entirely below onset of Bitter Springs anomaly after end of the anomaly 


\begin{tabular}{|c|c|c|c|c|c|}
\hline m & age & Formation & Member & height base (m) & age base (Ma) \\
\hline 2140 & 736.9 & \multirow{2}{*}{$\begin{array}{c}\text { lower Elbo- } \\
\text { breen Fm. }\end{array}$} & \multirow{5}{*}{$\begin{array}{l}\text { Petrovbreen Mb. } \\
\text { Russ } \varnothing \text { ya Mb. } \\
\text { Kinnvika Mb. } \\
\text { Backlundtoppen Fm. (lower) }\end{array}$} & 2130 & 737.8 \\
\hline 2100 & 740.6 & & & 1961 & 751.9 \\
\hline 2050 & 745.0 & \multirow{2}{*}{$\begin{array}{c}\text { Backlund- } \\
\text { toppen Fm. } \\
\end{array}$} & & 1894.1 & 756.5 \\
\hline 2000 & 749.0 & & & 1439.6 & 780.0 \\
\hline 1950 & 752.7 & Draken Fm. & & 1126 & 791.6 \\
\hline 1900 & 756.1 & \multirow{4}{*}{$\begin{array}{l}\text { Svanberg- } \\
\text { fjellet Fm. }\end{array}$} & \multirow{6}{*}{$\begin{array}{l}\text { Upper Limestone member } \\
\text { Upper Algal Dolomite member } \\
\text { Lower Limestone member } \\
\text { Lower Dolomite member } \\
\text { Upper Grusdievbreen member } \\
\text { Lower Grusdievbreen member }\end{array}$} & 1059.6 & 793.7 \\
\hline 1850 & 759.3 & & & 947.1 & 797.1 \\
\hline 1800 & 762.4 & & & 780.2 & 801.8 \\
\hline 1750 & 765.2 & & & 660 & 804.9 \\
\hline 1700 & 767.9 & \multirow{2}{*}{$\begin{array}{l}\text { Grusdiev- } \\
\text { breen Fm. }\end{array}$} & & 462 & 809.7 \\
\hline 1650 & 770.5 & & & 0 & 819.3 \\
\hline 1600 & 772.9 & & & & \\
\hline 1550 & 775.3 & & & & \\
\hline 1500 & 777.5 & & & & \\
\hline 1450 & 779.6 & & & & \\
\hline 1400 & 781.7 & & & & \\
\hline 1350 & 783.6 & & & & \\
\hline 1300 & 785.5 & & & & \\
\hline 1250 & 787.3 & & & & \\
\hline 1200 & 789.1 & & & & \\
\hline 1150 & 790.8 & & & & \\
\hline 1100 & 792.4 & & & & \\
\hline 1050 & 794.0 & & & & \\
\hline 1000 & 795.6 & & & & \\
\hline 950 & 797.1 & & & & \\
\hline 900 & 798.5 & & & & \\
\hline 850 & 799.9 & & & & \\
\hline 800 & 801.3 & & & & \\
\hline 750 & 802.6 & & & & \\
\hline 700 & 803.9 & & & & \\
\hline 650 & 805.2 & & & & \\
\hline 600 & 806.4 & & & & \\
\hline 550 & 807.6 & & & & \\
\hline 500 & 808.8 & & & & \\
\hline 450 & 810.0 & & & & \\
\hline 400 & 811.1 & & & & \\
\hline 350 & 812.2 & & & & \\
\hline 300 & 813.3 & & & & \\
\hline 250 & 814.3 & & & & \\
\hline 200 & 815.4 & & & & \\
\hline 150 & 816.4 & & & & \\
\hline 100 & 817.4 & & & & \\
\hline 50 & 818.3 & & & & \\
\hline 0 & 819.3 & & & & \\
\hline
\end{tabular}

